\title{
$\square$
}

\section{On the Size and Growth of Government}

\author{
Thomas A. Garrett and Russell M. Rhine
}

The size of the U.S. federal government, as well as state and local governments, increased dramati-
cally during the 20th century. This paper reviews several theories of government size and growth
that are dominant in the public choice and political science literature. The theories are divided
into two categories: citizen-over-state theories and state-over-citizen theories. The relationship
between the 16th Amendment to the U.S. Constitution and the timing of government growth is
also presented. It is likely that portions of each theory can explain government size and growth,
but the challenge facing economists is to develop a single unifying theory of government growth.

Federal Reserve Bank of St. Louis Review, January/February 2006, 88(1), pp. 13-30.

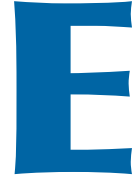

conomists have long been divided on the role of government in a society. ${ }^{1}$ John Maynard Keynes and John

Kenneth Galbraith have argued that an economy needs to be continually fine-tuned by an activist government to operate efficiently ${ }^{2}$ : Thus, as an economy grows, a growing government is also necessary to correct private-sector inefficiencies. This school of thought grew primarily out of the Great Depression, when markets seemed to fail and government intervention was viewed as the means to restore economic stability. Other 20th century economists, such as Frederick von Hayek and Milton Friedman, have argued that an activist government is the cause of economic instability and inefficiencies in the private sector. ${ }^{3}$ Government should exist to ensure that

1 The evolution of this debate is presented in Yergin and Stanislaw (2002).

2 John Maynard Keynes's book, The General Theory of Employment, Interest, and Money, is one of the most influential economic books of the 20th century. Keynes states the need for substantial increases in government spending during times of economic contractions. Similarly, John Kenneth Galbraith argued for an expansionary fiscal policy to increase economic activity and employment. a private market operates efficiently; it should not act to replace the market mechanism.

Various data clearly suggest that the size of the federal government in the United States has grown dramatically during the 20 th century. ${ }^{4}$ One measure of government growth is federal expenditures per capita. The history of real (2000 dollars) federal government expenditures per capita from 1792 to 2004 is shown in Figure 1. This growth did not occur gradually, however. In the early years of the United States, the federal government spent about $\$ 30$ per person annually. By the 1910s, government expenditures per capita were about $\$ 129$, or slightly more than four times the 1792 level. In 2004, the federal government spent $\$ 7,100$ per capita, nearly 55 times more than was spent per capita in the 1910s. Spending growth did slow in the mid-1980s and actually decreased

3 Of the many publications of both these Nobel Prize-winning economists, the most influential are Hayek's The Road to Serfdom and Milton Friedman and Anna Schwartz's A Monetary History of the United States 1867-1960.

4 All data on federal, state and local government expenditures are from the Office of Management and Budget (www.whitehouse.gov/ omb) and the U.S. Census Bureau.

Thomas A. Garrett is a research officer at the Federal Reserve Bank of St. Louis, and Russell M. Rhine is an assistant professor at St. Mary's College of Maryland. Lesli Ott provided research assistance.

(c) 2006, The Federal Reserve Bank of St. Louis. Articles may be reprinted, reproduced, published, distributed, displayed, and transmitted in their entirety if copyright notice, author name(s), and full citation are included. Abstracts, synopses, and other derivative works may be made only with prior written permission of the Federal Reserve Bank of St. Louis. 


\section{Table 1 \\ Cabinet Departments}

\begin{tabular}{lc} 
Department & Year established \\
\hline State & 1789 \\
Treasury & 1789 \\
Justice & 1789 \\
Defense* & 1789 \\
Interior & 1849 \\
Agriculture & 1889 \\
Commerce & 1913 \\
Labor & 1913 \\
Health and Human Services & 1953 \\
Housing and Urban Development & 1965 \\
Transportation & 1966 \\
Energy & 1967 \\
Education & 1979 \\
Veterans Affairs & 1987 \\
Environmental Protection Agency & 1990 \\
Homeland Security & 2002
\end{tabular}

NOTE: *The date refers to the Department of War; the Department of Defense was officially created in 1949. The Department of War (1789), the Department of the Navy (1798), the Department of the Army (1947) and the Department of the Air Force (1947) were all reorganized under the Department of Defense in 1949. See www.dod.gov.

${ }^{\dagger}$ Cabinet-level rank under George W. Bush;

see www.whitehouse.gov/government/cabinet.html.

SOURCE: Cabinet department websites.

in the mid-1990s. By the year 2000, however, per capita spending increased once again.

It is clear from Figure 1 that spending on national defense can have a substantial impact on the level of government spending. Figure 2 is a graph of total per capita expenditures with and without defense spending over the period 19472004. It is evident that the long-term growth in total per capita government spending is not solely a function of national defense.

Federal spending has also increased relative to gross domestic product (GDP) throughout much of this country's history, as seen in Figure 3. Expanded government during World War II is clearly evident in Figure 3, as is the slowdown in government growth during the 1980s and 1990s.
Figure 1 shows that the federal government has historically spent more per person each year, but Figure 3 suggests that this growth in spending has been less than the growth in GDP at the end of the 20th century.

An examination of the components of federal government spending provides insight into which areas the government has increased activity.

Figure 4 plots several components of federal government spending per capita from 1947 to 2004. Although total per capita spending increased following World War II, several components of federal government expenditures stayed relatively constant or even decreased slightly over the next 50 years: physical resources (e.g., transportation, energy), national defense, and "other functions" (e.g., agriculture, general government, international affairs). In fact, much of the reduction in federal expenditures per person occurring in the mid- to late 1990s can be attributed to a reduction in national defense spending. However, spending on national-debt net interest payments and human resources grew substantially over the same period. The dramatic increase in human resources that occurred reflects the growth in Social Security payments and the inception of entitlement programs such as Medicare (in 1965).

Another measure of the size of the federal government is the number of cabinet departments. Eight cabinet departments were created from 1788 to 1952 . Since 1953 , there have been an additional eight cabinet departments established. Table 1 provides a list of all executive cabinet departments and the dates they were each established. One can infer from Table 1 and Figure 1 that the increase in per capita expenditures during the 20th century was due to an increase in the physical size of government as well as an increase in spending by existing government agencies.

In addition to the increase in federal government expenditures, state and local government expenditures per capita have also increased since World War II, as seen in Figure 5. Inflation-adjusted expenditures per person were about $\$ 759$ in 1948 , compared with over $\$ 4,300$ per person in 2004 . The average annual growth rate in real per capita state and local government expenditures was 3.2 percent, compared with an average annual growth 
Figure 1

Real Per Capita Federal Expenditures: 1792-2004

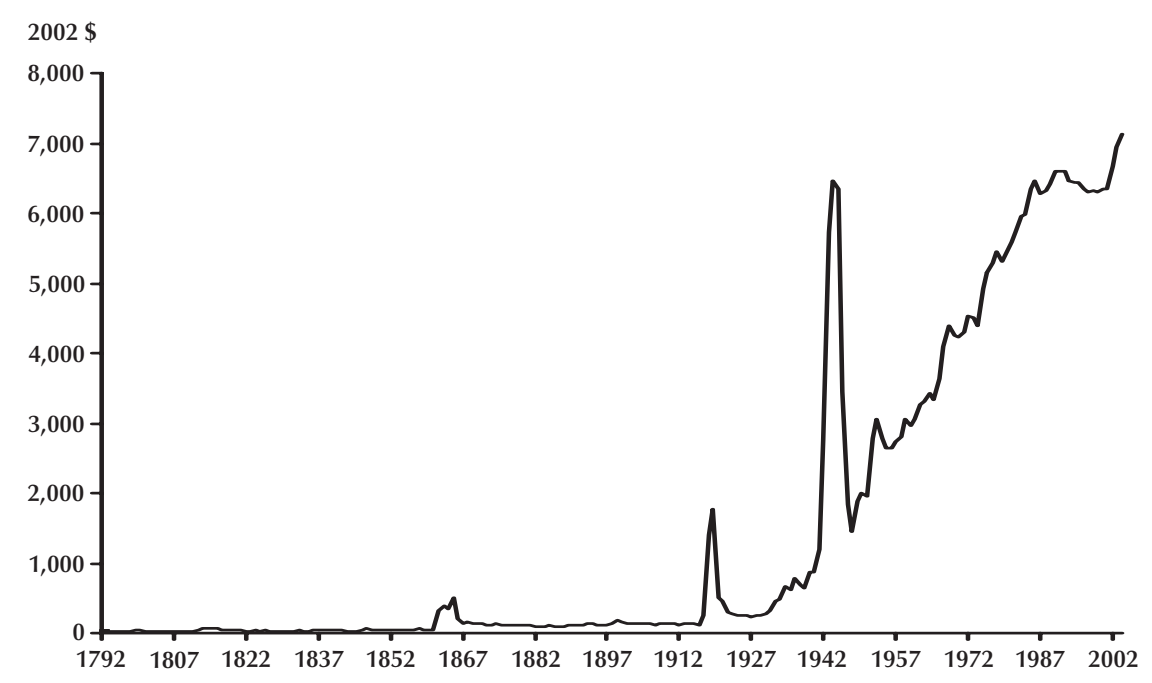

Figure 2

Real Per Capita Federal Expenditures: 1947-2004

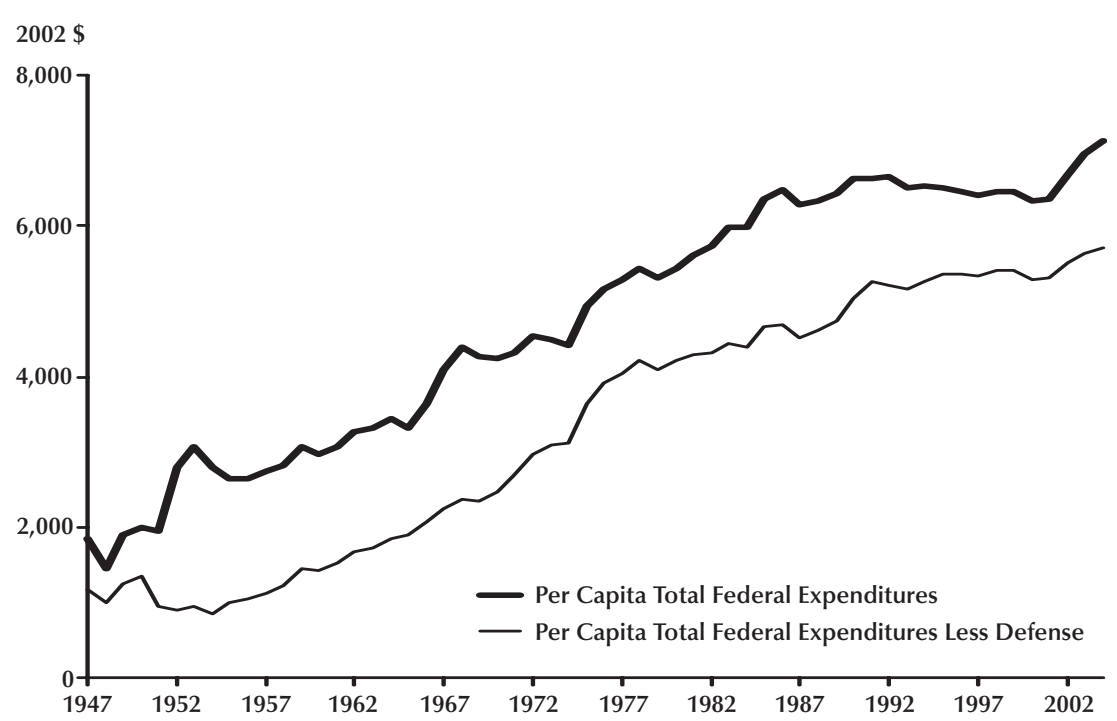




\section{Garrett and Rhine}

Figure 3

Total Federal Expenditures as a Percent of GDP: 1930-2004

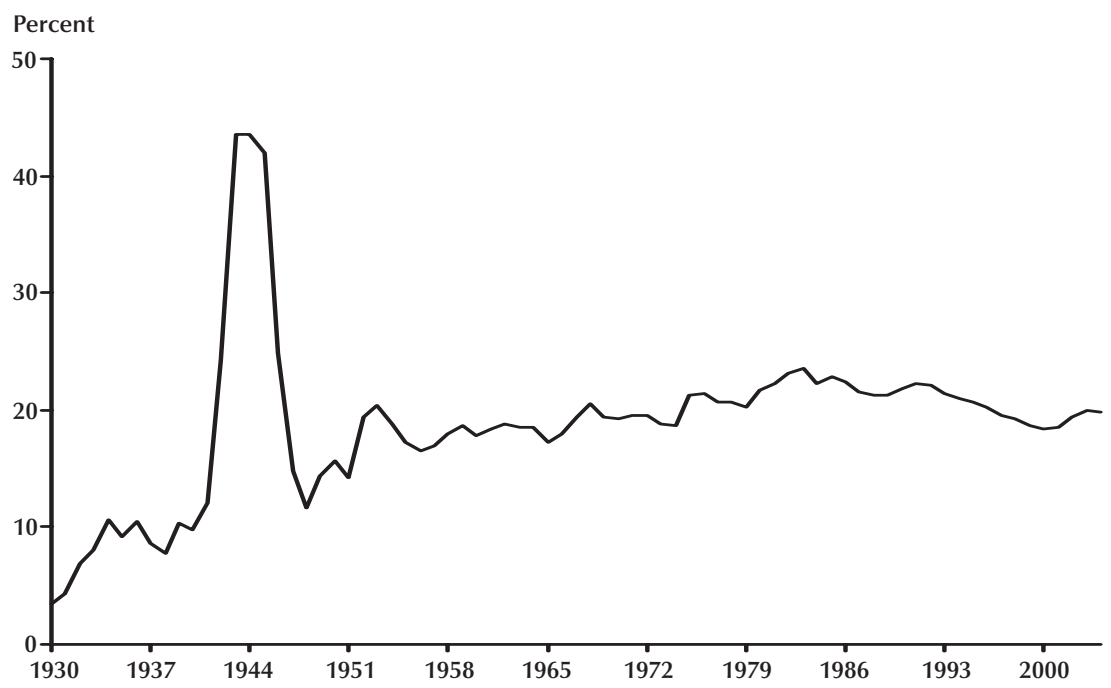

Figure 4

Real Per Capital Federal Expenditures by Component: 1947-2004

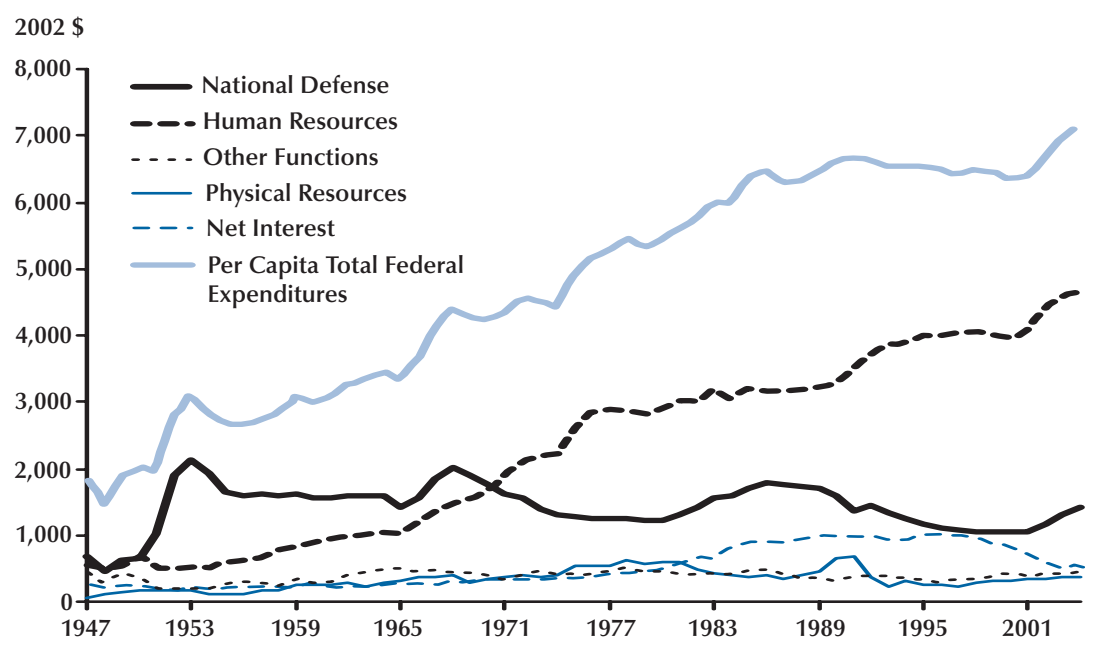




\section{Figure 5}

\section{Real Per Capita State and Local Government Expenditures: 1948-2004}

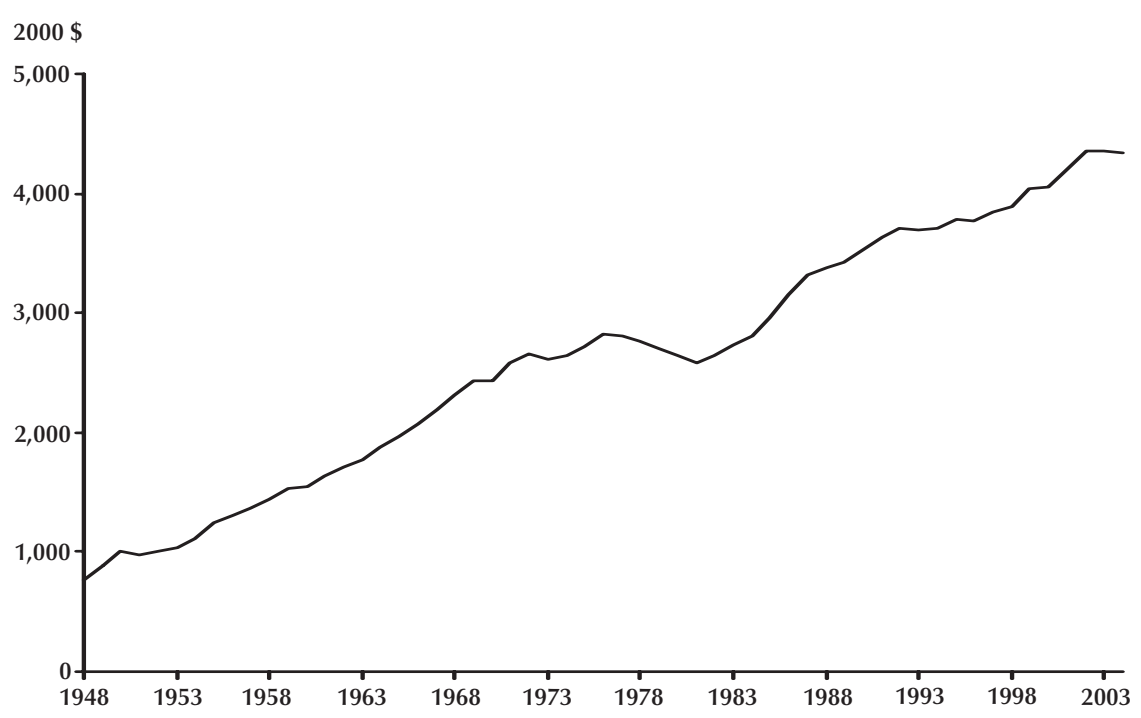

rate of 2.7 percent for real federal expenditures per person. Total government expenditures per person (federal + state + local) totaled $\$ 2,350$ in 1948 and nearly $\$ 12,150$ in 2004.

The data illustrated in Figures 1 through 5 provide convincing evidence that the size of government in the United States has grown throughout the 20th century. ${ }^{5}$ An important question asked by economists and political scientists is why this growth has occurred. This paper presents several popular theories of government size and growth that have received attention in the economics and

5 Another measure of government size is federal employment relative to total employment. Plotting this series over time reveals that federal employment is a diminishing share of total employment throughout the 20th century. A closer inspection of the data reveals that most of this decrease in federal employment is a result of a reduction in defense employment, which suggests that the number of federal government employees is not a good measure of the size of the government because subcontractors complete much of their work. For example, the federal government does not build military aircrafts; they pay subcontractors like Lockheed-Martin to build them. So, thousands of people working on the construction of aircrafts at Lockheed-Martin receive their pay indirectly from the federal government, and they are not included in government employment figures. In 2004, Lockheed-Martin had sales of $\$ 35.5$ billion. Nearly 80 percent of sales were to the U.S. Department of Defense/Intelligence and Civil Government/Homeland Security (www.lockheedmartin.com). political science literature. ${ }^{6}$ Since government and the citizenry are made up of individuals, all theories of government considered here approach the issue from a microeconomic perspective; specifically, they consider the incentives of voters, public officials, and the inherent inefficiencies that may arise in a representative democracy. Note that some theories are better suited to explain government size and others to explain government growth.

The theories of government size and growth fall into two distinct categories. The first category is citizen-over-state theories of government. These theories begin with the premise that citizens demand government programs and, as a republic, the government is simply responding to the will of the people. The other category is state-overcitizen theories of government growth. Here, the size of government is independent from citizen demand and government grows because of inherent inefficiencies in public sector activities and incentives facing government bureaucrats. The paper concludes with a discussion of the potential

6 Kliesen (2003) discusses the increase in government size during the 20th century. 
importance of the 16th Amendment to the U.S. Constitution, which allows the federal government to tax wage and business income. As will be discussed, the timing of the 16th Amendment and the start of government growth may be more than a coincidence.

\section{CITIZEN-OVER-STATE THEORIES OF GOVERNMENT SIZE AND GROWTH}

The citizen-over-state theories of government size and growth begin with the premise that government growth occurs because citizen demand for government programs has increased over time. It will become evident here that the demand for government can come from individual citizens or a collection of citizens organized into special interest groups. This section discusses three distinct citizen-over-state theories of government size and growth.

\section{The Government as a Provider of Goods and a Reducer of Externalities}

Voters decide which goods the government will provide and which negative externalities the government will correct. ${ }^{7}$ The tool economists and other social scientists use to determine where the government will intervene is the median voter theorem. Hotelling (1929) and Downs (1957 and 1961) rank voters by political ideology and place the most conservative individual on the far right and the most liberal on the far left. Assuming a two-party system, the voters must choose the conservative candidate or the liberal candidate. Since the voter will choose the candidate with the views closest to his or her own views, whichever candidate wins the median voter will have a majority of votes and win the election.

An assumption of the median voter theorem is the use of majority rule voting. Additional assumptions are that citizens vote directly on government spending issues and that government

\footnotetext{
7 A negative externality is a negative (costly) spillover from an activity onto a nonconsenting third party. An example is pollution from a factory that is dumped into a river and has an adverse affect on everyone downstream.
}

spending is the only issue on the ballot. Thus, the median voter determines the demand for publicly provided goods, which is a function of income, the relative price of public goods to private goods, and tastes.

The price elasticity of demand for government and the price of government both determine whether government grows or contracts. Government will grow if the demand for government is price inelastic and the price of government increases. In other words, if the price of government goods or services increases and the quantity demanded of the goods or services does not decrease by a proportionate amount, total government spending increases. The other possibility for government growth is an elastic demand for government and a falling price of government. That is, if the price of government goods or services decreases and the quantity demanded of the goods or services increases by a more-than-proportionate amount, total spending increases.

The literature presents evidence in support of an increasing price and an inelastic demand for government. Baumol (1967) addresses the issue of relative private and public sector prices in terms of government growth. He shows that the increase in the price of the public sector goods and services relative to the price of the private sector goods and services is due to productivity gains in manufacturing. Since most government programs are services (i.e., national defense, education, and police), they have not experienced the same efficiency gains as manufacturing specifically and the private sector overall; thus, the relative price of public goods has been increasing.

Mueller (2003) presents additional evidence of the Baumol (1967) effect in OECD countries. ${ }^{8}$ He found that 20 of the 25 OECD countries showed the expected growth in government expenditures as a percent of GDP from 1960 to 1995. Of the five countries that did not increase government expenditures by the amount predicted by the Baumol effect, four of the five still increased to some extent and only one decreased. It decreased

\footnotetext{
8 OECD is the Organization of Economic Cooperation and Development: OECD countries are listed at www.oecd.org.
} 
expenditures as a result of decreased defense spending after the end of the Cold War.

In addition to the productivity differences, Ferris and West (1999) found that wages in the public sector, which contribute to the price of government, are increasing faster than in the private sector. They find evidence of this in the salaries of unionized versus non-unionized public school teachers. The near-monopoly nature of publicly provided goods and services encourages the creation of unions, and they will demand higher wages. The government will appease the unions and simply pass these costs onto the taxpayers.

The remaining determinant that the literature uses to help explain the government as a provider of goods and services and reducer of externalities is citizen tastes and preferences. Over time taste for publicly provided goods and services changes and subsequently so will the demand for these goods and services. One such good is the redistribution of income and wealth for insurance purposes. Rodrik (1998) looks at the risk associated with open economies and presents evidence to support the hypothesis that the more open the economy, the larger the government. Specifically, he argues that the volatility of income and employment that corresponds with open economies is an insurable risk. The government programs that act as a form of insurance to protect workers are social programs (i.e., unemployment and social security). ${ }^{9}$

However, as pointed out by Mueller (2003), a problem with Rodrik's (1998) findings is that the large social programs in the United States grew at a time of significant slowdown in the domestic economy-the Great Depression-not the increased openness of the U.S. economy. Thus, social insurance programs are meant to reduce the risk of households' income volatility due, at least in part, to business cycles. The programs also attempt to smooth cash flow over a citizen's lifetime and across income levels.

9 Ex post, not all citizens will benefit from social programs, as suggested by Garrett and Rhine (2005), which shows that less than 5 percent of 2003 retirees benefit from the Social Security system. Ex ante, however, the social program is publicly provided insurance.

\section{The Government as a Redistributor of Income and Wealth}

The second citizen-over-state theory of government surmises that government serves as a redistributor of income and wealth. All government programs are seen as mechanisms for redistribution. Meltzer and Richard (1978, 1981, 1983) present a model where leisure is inversely related to the fraction of total time worked, consumption is inversely related to the tax rate and is positively related to a lump-sum grant received from the government, and income is positively related to productivity. Their model produces a well-known result-a higher level of productivity equates to a higher level of income, and the higher income increases consumption and well-being.

Meltzer and Richard $(1978,1981,1983)$ show that individuals will demand the combination of tax rates and lump sum payments that maximizes their well being. Individuals with a lower level of productivity, and subsequently a lower level of income, will demand a higher tax rate and a higher lump-sum payment from the government. The extreme case is individuals that do not work and pay no taxes; they will simply want to maximize their lump-sum payment and will demand a higher tax rate than that demanded by those individuals who are working. This model explains the growth in government in part because, over time, new entrants into the voting population are lower income workers. These lower income workers will cast votes for the candidate who will levy higher taxes and increase the amount of redistribution.

Kristov, Lindert, and McClelland (1992) explain that the amount of redistribution is based on social affinity. The closer the middle class feels to the poor, or the slower incomes are growing, the greater the amount of redistribution. The authors study the period immediately preceding and during the Great Depression as support for their claim. They explain that, when the economy was expanding, Americans voted not to increase taxes to fund relief for the poor. But, after the economy changed directions in the 1930s, social programs increased dramatically. Taxes on high earners increased, and the number of programs 


\section{Garrett and Rhine}

that redistributed income and wealth increased as well.

Peltzman (1980) explains that candidates promise transfer payments to groups of citizens in order to gain their support. If the distribution of incomes over different socio- economic classes is similar, then the candidate must offer a greater amount of redistribution to gain supporters. With a trend toward more evenly distributed incomes in years prior to the Peltzman (1980) study, greater redistribution by the federal government was undertaken.

\section{Interest Groups}

Interest groups can increase the size of government by organizing members and applying political pressure more effectively than individual citizens (Olson, 1965, and Moe, 1980). Examples of interest groups mentioned frequently in the popular press include the Sierra Club, the National Organization of Women, and the National Rifle Association. One can think of an interest group as an organized collection of individual voters (or businesses) having the same preference for a specific policy. Through concentrated lobbying, an interest group can obtain a desired policy that has direct benefits for the interest group but the costs of the policy are spread across millions of taxpayers. Elected officials play a key role in this process as they weigh the political costs and benefits of each policy. Such disconnectedness between costs and benefits will result in inefficient levels of government expenditures-that is, the societal costs of the policy will be greater than the societal benefits.

Supply and demand analysis can be used to model an interest group economy (McCormick and Tollison, 1981). "Demanders" of a policy will be those groups that can organize and lobby for, say, $\$ 100$ at a cost of less than $\$ 100$. "Suppliers" (individual tax-payers) are those for whom it would cost more than $\$ 100$ to lobby against losing that $\$ 100 .{ }^{10}$ The incentives facing elected officials are such that they will target unorganized suppliers

${ }^{10}$ As suggested by Mueller (2003), the term suppliers should be taken loosely because individuals would only likely engage in the transfer under coercion. with low losses from any transfer while courting demanders who are organized and active in the political process. Thus, costs are spread across many taxpayers but the benefits are concentrated within the interest group. If too little or too much wealth is transferred, the political process will discipline the elected official at the polls.

Although economic theory can be used to explain how interest groups operate in a political market for transfers, economics has said little about how interest groups form (Olson, 1965). In fact, economic theory suggests that there would be little or no interest group formation because of the free-rider problem. Because the benefits of lobbying are nonrival and nonexcludable, it is rational for individuals who would benefit from lobbying to free-ride. ${ }^{11}$ Despite a lack of theory for interest group formation, economics has produced dozens of papers that provide theoretical and empirical evidence on the link between interest groups and the size of government. ${ }^{12}$

Weingast, Shepsle, and Johnsen (1981) offer a rational explanation for the inefficiency (costs > benefits) of special interest projects. The authors focus on distributive policies that concentrate benefits within a geographic area and disperse the costs (taxes) over all constituencies. In the model of Weingast, Shepsle, and Johnsen, the national constituency is divided into districts that are each assumed to maximize its net benefits from any redistributive project and have only one representative. Because the district is only a fraction of the national constituency, the cost of the project is spread out over the entire constituency. Each district does not take into account the costs that are being placed on other constituencies when evaluating its own benefits. Thus, because the net benefits of a given project are overstated, the

\footnotetext{
${ }^{11}$ There are several ways in which interest groups can, at least partially, overcome the free-rider problem. One way is through coercion or mandatory membership, such as in the case of labor unions and state bar associations. Other interest groups may provide valuable private benefits to members, such as publications and educational material, at a relatively low cost of joining. The American Association of Retired Persons (AARP) is an example. Political entrepreneurs can also overcome the free-rider problem. Examples include many large corporations that have offices in Washington, D.C. The employees of large corporations also serve as informal lobbyists.

${ }^{12}$ See Ekelund and Tollison (2001) for a detailed overview of the literature on interest group theory.
} 
project is larger than the efficient project size. Furthermore, because local projects are larger than the efficient level, the district's representative has even greater interest in acquiring projects that benefit his or her district.

Becker (1983) presents a theory of public policies that result from competition among special interest groups (or "pressure groups" according to Becker). Becker views political pressure as a public good. ${ }^{13}$ An increase in interest group membership will increase pressure, but because pressure is a public good, free-riding (by would-be group members) will increase. Because free-riding increases, so do the costs of implementing pressure. Becker finds that efficiency in producing pressure is partly determined by the costs of controlling pressure-a greater control over freeriding increases the amount of pressure. With higher amounts of pressure, a special interest group is able to acquire more benefits (lower taxes or higher subsidies). Becker believes that efficiency is improved not only by controlling the free-rider problem, but also through the competition that occurs between tax groups and subsidy groups that consider their losses via taxes or subsidies. Therefore, interaction among competing special interest groups increases the power of the special interest lobby, and thus special interest spending. ${ }^{14}$

Sobel (2001) provides empirical evidence on the positive relationship between political action committees (PACs) and federal government spending. ${ }^{15}$ He notes that the rise in federal government spending during the 1970s and 1980s and the subsequent slowdown in the 1990s parallel the

\footnotetext{
${ }^{13}$ A public good is nonrival (consumption by one person does not deny consumption by others) and nonexcludable (no price mechanism exists to deny consumption). National defense is a classic example of a public good.

${ }^{14}$ Note a key difference between Weingast, Shepsle, and Johnsen (1981) and Becker (1983): Weingast, Shepsle, and Johnsen believe interest groups arise as a result of concentrated benefits and dispersed costs that follow from the existence of independent districts (each district is an interest group), and it is this dispersion between costs and benefits that leads to larger government. Becker, however, believes that it is the competition among interacting interest groups that increases the power of the special interest lobby, and thus increases special interest spending.

${ }^{15}$ A PAC is an organization whose goal is to raise campaign funds for candidates seeking political office.
}

increase and eventual decrease in the number of PACs over this same period. He finds that a 10 percent increase (decrease) in the number of PACs in time $t-1$ is associated with a 1.07 to 1.57 percent increase (decrease) in federal spending in time $t$. However, one issue is whether the number of registered PACs, as opposed to PAC membership, accurately represents the scope and power of the special interest lobby in the United States.

Although interest group theory may provide, at least in part, a reasonable explanation for the size of government, it is not without its theoretical and empirical challenges. ${ }^{16}$ One issue is that of causality. Specifically, does interest group activity cause government spending, or do changes in the level of government spending influence interest group activity (Mueller and Murrell, 1985, 1986)? Another issue mentioned earlier is that of interest group formation. Although there are anecdotal explanations as to how interest groups can overcome the free-rider problem, such an idea has yet to be incorporated into a reasonable economic model. Finally, there is debate as to whether the interest group theory is in fact a citizen-over-state theory or a state-over-citizen theory given the pivotal role that elected officials play in the link between interest groups and government growth.

\section{STATE-OVER-CITIZEN THEORIES OF GOVERNMENT SIZE AND GROWTH}

The previous section discussed several citizenover-state theories of government size and growth. Inherent in these theories is the idea that government is demand driven-that is, government size and growth occur because citizen demand for government has increased. This demand for government can come from individual citizens or groups of citizens (the interest group theory), with each party having a desire for some form of a publicly provided good, externality reduction, or redistribution of income.

The following section presents several theories of government growth that start from a

\footnotetext{
${ }^{16}$ Ekelund and Tollison (2001).
} 


\section{Garrett and Rhine}

completely opposite premise from the previous theories-namely, that the size of government is supply driven rather than demand driven. These theories posit that the incentives facing public officials and the nature of our representative form of government provide an environment for government growth to occur in the absence of citizen demand. Government grows because of government and its inherent inefficiencies, structure (e.g., direct democracy versus a representative democracy), and incentives facing public officials. Appropriately, then, the following three theories are classified as state-over-citizen theories of government growth.

\section{Bureaucracy Theory}

Goods and services provided by the government do not arise out of thin air, but rather they must be created by a government agency. The supply of government output, then, may be a function not only of citizen demand (as the previous theories suggest), but also of the demand of government bureaucrats. Niskanen's (1971) theory of bureaucracy postulates that government bureaucrats maximize the size of their agencies' budgets in accordance with their own preferences and are able to do so because of the unique monopoly position of the bureaucrat. Because the bureaucrat provides output in response to his or her own personal preferences (e.g., the desire for salary, prestige, power), it is possible that the size of the bureaucrat's budget will be greater than the budget required to meet the demands of the citizenry. An important point is that bureaucracy theory does not deny the citizen demand models of government discussed in the previous section, but rather it suggests that bureaucrats can generate budgets that are in excess of what citizen demand warrants.

The ability of a bureaucrat to acquire a budget that is greater than the efficient level is dependent on several institutional assumptions (Niskanen, 1971, 2001). First, unlike private sector production, the public sector does not produce a specific number of units, but rather supplies a level of activity. As a result, this creates a monitoring problem for oversight agencies: It is difficult, if not impossible, for monitors to accurately judge the efficiency of production when no tangible or countable unit of output is available. Second, the monopoly nature of most bureaus shields them from competitive pressures necessary for efficiency and also denies funding agencies (Congress, the executive branch) comparable information on which to judge the efficiency of the bureau. Third, only the bureau knows its true cost schedule because bureau funding is provided by agents external to the bureau. This provides an opportunity for bureaucrats to overstate their costs in order to receive a larger budget. Finally, the bureaucrat can make take-it-or-leave-it budget proposals to the funding agency.

Niskanen (1971) shows that the bureaucrat will maximize a budget subject to the constraint that the budget must cover the costs of producing the good or service. The implication of the model is that the bureau's budget (and output) is expanded beyond the point where the marginal public benefits of the good or service equals the bureau's marginal costs of providing the good or service. ${ }^{17}$

Although the model presents clear reasoning on how a bureau can expand output and costs beyond the efficient level, in reality many bureaus cannot expand output beyond the level demanded by the citizenry. Examples of this at the local level include school districts and garbage collection: School districts cannot educate more students than those who are already attending school,

\footnotetext{
${ }^{17}$ A simple formulation of Niskanen's (1971) model of bureaucracy is:

- $B=B(Q)$, where $B$ is the bureau's budget and $Q$ is the perceived output of the bureau. The funding agency is aware of this public benefit schedule, $B(Q)$. It is assumed that $B^{\prime}>0$ and $B^{\prime \prime}<0$.

- $C=C(Q)$, where $C$ represents the bureau's cost function, which is known only to the bureau. Also, $C^{\prime}>0$ and $C^{\prime \prime}>0$.
}

The bureaucrat is assumed to maximize his or her budget subject to the constraint that the budget must cover the costs of producing $Q$. Thus, the bureau's objective function is

$$
O_{B}=B(Q)+\lambda(B(Q)-C(Q)) \text {. }
$$

Differentiating with respect to $Q$ and $\lambda$ and then rearranging terms gives

(1)

$$
\begin{gathered}
\frac{\partial B}{\partial Q}=\frac{\lambda}{(1+\lambda)} \frac{\partial C}{\partial Q} \\
B(Q)=C(Q) .
\end{gathered}
$$

Mueller (2003, Chap. 16) provides a detailed analysis of bureaucracy theory and presents extensions of the model presented here that relax several of the initial assumptions. 
and garbage collectors cannot haul more garbage than is available for disposal. Even in these cases, however, a bureau may expand its budget beyond the efficient level-not by providing output beyond the efficient amount but by providing the services at a higher cost than necessary.

There has been ample literature that has compared the costs of public and private organizations that provide similar services. The activities or firms studied include, but are not limited to, hospitals (Clarkson, 1972), refuse collection (Bennett and Johnson, 1979, and Kemper and Quigley, 1976), water utilities (Morgan, 1977) and fire protection (Ahlbrandt, 1973). Mueller (2003, Chap. 16) provides a summary of 70 studies that examined the cost of public versus private sector provision of identical services. In all but five studies cited, the cost of public provision is significantly greater than private provision, thus lending support for the bureaucracy theory of government.

However, the cost difference between private and public organizations may simply be a result of a lack of competitive pressure rather than direct attempts by bureaucrats to maximize their budget. In addition, Mueller (2003) suggests that many of the assumptions necessary for the bureaucracy theory to hold may be too strong and actually weaken the ability of the bureaucrat to manipulate price and output.

For example, the ability of a bureau to present a take-it-or-leave-it budget proposal may be lessened if the funding agency or an oversight agency is aware of the advantage such a position affords the bureau. Thus, the funding agency may request that the bureau present several cost and output scenarios; if the bureau must present a cost schedule, it becomes more likely that the bureau will announce its true costs. ${ }^{18}$ Also, several agencies exist, such as the U.S. General Accounting Office, that are set-up for the sole purpose of detecting excessive costs and inefficiencies in government bureaus. The possibility of an audit and the negative attention such an action brings creates an

\footnotetext{
${ }^{18}$ Bendor, Taylor, and Van Gaalen (1985) show that a bureau can charge a price higher than the efficient level (marginal costs = marginal benefits) only when the demand for the bureau's service
} is inelastic. incentive for bureaucrats to limit their pricing power and, at least somewhat, promote an efficient organization.

Although the constraints on bureaucracy seem reasonable, they are somewhat limited given the number of local, state, and federal agencies that exist relative to the number of funding and oversight agencies. However, although the literature has presented strong evidence that bureaucracy may partly explain government size, much less work has been done on explaining how bureaucracy theory may explain government growth. One explanation put forth by Mueller (2003) is that the ability of a bureau to misrepresent its cost and/or output schedule is likely to be directly correlated with the bureau's size. Thus, larger bureaus can better manipulate their budgets relative to smaller bureaus, and any manipulation of the bureau's budget will increase the size of the bureau, which in turn increases the bureau's ability to manipulate the budget.

Despite the limits of bureaucracy theory, it remains a plausible explanation for the scope of government seen today. The common inefficiencies of large organizations, be they private or public, are not unknown by the general public, who often work in such organizations. In addition, it is not uncommon for the media to report waste or fraud that has occurred at large private and public organizations. The bureaucracy theory fits arguably well with the real-world experiences of many people.

\section{Fiscal Illusion}

The fiscal illusion theory assumes that government, specifically legislators and the executive branch, can deceive voters as to the true size of government. This theory is similar to the bureaucracy theory that postulated that bureaus can deceive legislators and funding agencies as to the true size of the bureau. The concept of fiscal illusion has been discussed in the economics literature for nearly a century, but Buchanan (1967) formulates the idea into a theory of government size and growth.

Fiscal illusion assumes that citizens measure the size of government by the quantity of taxes they pay. As such, taxes and tax collection meas- 


\section{Garrett and Rhine}

ures that are less obvious to citizens are more likely to be used by government. Examples include the federal withholding of income taxes and property tax collection through monthly mortgage payments. Although the income tax is considered a direct tax, versus indirect taxes such as gasoline or cigarette taxes, the ability of direct taxes to be disguised suggests that the collection method of some direct taxes may hide citizens' tax bills better than indirect taxes. Mueller (2003, p. 527) suggests that determining which taxes are hidden from citizens is largely an empirical issue.

Oates (1988) provides an overview of the empirical literature on fiscal illusion. He summarizes the empirical findings and develops five hypotheses to support the fiscal illusion theory of government. Oates (1988) concludes (i) tax burdens are more difficult to evaluate when the tax structure is more complicated, (ii) progressive tax structures that increase a citizen's tax bill according to income increases are less obvious than legislated changes to the tax code, (iii) homeowners are better able to judge their portion of property taxes than are renters, (iv) the issuance of debt (and thus the likelihood of future tax increases) appears less costly to voters than current tax increases, and (v) the "fly-paper effect" of government spending is real.

The fly-paper effect hypothesis deserves some explanation given the attention it has received in the literature (see Hines and Thaler, 1995). Economic theory predicts that a lump-sum increase in income to one level of government from another, say a lump-sum grant from the federal government to a state government, will increase government spending by the same amount as would an equal increase in citizen income in that state. Increases in income (revenue via taxes) or grants to the voter's government are identical because they both increase financial resources to the government. Government sets the level of expenditures desired by the median voter. Thus, when grant monies are obtained by the government, the voter can consider these grant funds as an increase in personal income via a reduction in taxes. Thus, through an efficient political process, any additional revenue from grants is offset by a decrease in tax revenue demanded by voters.

Typically, a \$1 increase in personal income increases government spending by $\$ 0.05$ to $\$ 0.10 .^{19}$ In the absence of a fly-paper effect, one should expect to see every $\$ 1$ from a lump-sum grant to state governments (an income increase to state governments) increase government spending by the same amount, $\$ 0.05$ to $\$ 0.10$. However, the literature has shown that lump-sum grants increase government spending by $\$ 0.20$ to $\$ 1$ for every $\$ 1$ in grant money, which is significantly greater than the $\$ 0.05$ to $\$ 0.10$ increase that would arise from an increase in median voter income. ${ }^{20}$ Thus, the grant-money "sticks" to where it is sent, hence the term fly-paper effect. Inefficiencies in the political process and a disconnect between the preferences of the median voter and government are cited as reasons why the fly-paper effect may exist. If the fly-paper effect exists, then governments can increase spending without apparent tax increases. Increases in intergovernmental grants will need to be financed by taxes, but this tax revenue (and resulting tax burden on citizens) is not directly linked to the expenditures by the state governments.

The fly-paper effect and the broader issue of fiscal illusion are not without critics. Doubters of the fly-paper effect argue that incorrect modeling of empirical models and the political processes in the public sector as well as the failure to discern between numerous types of grants may explain the fly-paper effect found in the literature (Hamilton, 1983, and Chernick, 1979). ${ }^{21}$ Regarding fiscal illusion, the literature does not explain exactly how government will grow if fiscal illusion is indeed present. Just because voters are unaware

\footnotetext{
${ }^{19}$ Hines and Thaler (1995) and Fisher (1996).

${ }^{20}$ Hines and Thaler (1995) summarize the results of numerous studies that present empirical estimates of the fly-paper effect.

${ }^{21}$ Grants can be lump-sum, matching (where the receiving government must match a certain percent of the expenditure), closed-ended, or open-ended. Whereas a lump-sum grant only creates an income effect, a matching grant creates both an income effect and a substitution effect. Economic theory predicts that matching grants will result in higher government spending than lump-sum grants (see Fisher, 1996, Chap. 9). Disentangling the effects of various forms of grants greatly complicates empirical analyses on the fly-paper effect.
} 


\section{Table 2}

\section{Vote Trading, Bundling, and Government Size}

Net Benefits (+) or Costs (-) to Each Voter in District

\begin{tabular}{|c|c|c|c|c|}
\hline Voters of district & $\begin{array}{l}\text { Construction of } \\
\text { post office in } A\end{array}$ & Dredging harbor in B & $\begin{array}{l}\text { Construction of } \\
\text { military base in C }\end{array}$ & Total \\
\hline A & $+\$ 10$ & $-\$ 3$ & $-\$ 3$ & $+\$ 4$ \\
\hline B & $-\$ 3$ & $+\$ 10$ & $-\$ 3$ & $+\$ 4$ \\
\hline C & $-\$ 3$ & $-\$ 3$ & $+\$ 10$ & $+\$ 4$ \\
\hline $\mathrm{D}$ & $-\$ 3$ & $-\$ 3$ & $-\$ 3$ & $-\$ 9$ \\
\hline$E$ & $-\$ 3$ & $-\$ 3$ & $-\$ 3$ & $-\$ 9$ \\
\hline Total & $-\$ 2$ & $-\$ 2$ & $-\$ 2$ & $-\$ 6$ \\
\hline
\end{tabular}

SOURCE: Gwartney and Stroup (1997, p. 503).

of their true tax bill, that does not mean there is a clear method for government officials (legislators, bureaucrats) to take advantage of this situation to increase the size of government. Mueller (2003) argues that, for fiscal illusion to explain government size and growth, it must be combined with other theories of government growth discussed earlier to form a single model of government growth.

\section{Monopoly Government and Leviathan}

The idea that representative governments behave as monopolists was first suggested by Breton (1974). The party in control of the legislature has an objective function that includes the probability of reelection, personal pecuniary gain, and the pursuit of personal ideals. While providing basic public goods, such as police and fire protection (in the case of a local government), the monopoly government can obtain its objectives by bundling narrowly defined issues that benefit individual members of the government along with the more popular public-good services provided.

This idea stems from the neoclassical view of the monopolist, where a private monopolist can increase his profit by bundling other products that he does not monopolize with his monopolist product. Consumers will then buy the monopolist's package as long as their consumer surplus on the bundled products exceeds the cost of the individual packages.

In the case of governments, this bundling of services results in higher levels of government output. Tullock (1959) provides a comprehensive analysis of how the bundling of goods and votetrading among legislators can increase the size of government. The example shown in Table 2 illustrates the point made by Tullock (1959): A five member legislature is considering the three projects, each of which is inefficient because the net costs outweigh the net benefits. ${ }^{22}$ As a result, if each project was voted on separately (and each legislator voted according to the preferences of his constituency), then none of the projects would be implemented because each would lose by a 4to-1 margin. But, bundling the three projects will garner "yes" votes from legislators representing districts $\mathrm{A}, \mathrm{B}$, and $\mathrm{C}$, thus allowing the legislation to pass 3-to-2, thereby increasing the size of government expenditures.

The monopolist view of government has been extended further by Brennan and Buchanan $(1977,1980)$. In their model of a "leviathan" government, the monopoly government's sole objective is to maximize revenue. The citizenry is assumed to have lost all control over their govern-

22 As noted in Gwartney and Stroup (1997, p. 503), vote-trading and bundling can also lead to efficient measures. The point made in the above example is that bundling can lead to greater government size. 


\section{Garrett and Rhine}

ment, and political competition is seen as an ineffective constraint on the growth of government. ${ }^{23}$ Their leviathan view of government is opposite of the government assumed in the citizen-overstate theories-the latter being a benevolent provider of goods, a reducer of externalities, and a redistributor of income. According to Brennan and Buchanan (1977), only constitutional constraints on the government's authority to tax and issue debt can limit a leviathan government. ${ }^{24}$

Empirical evidence for the monopoly view of government has provided mixed results. The studies are often conducted at the local rather than national level due to data availability. Many tests for monopoly government have a similar goal as those for the bureaucracy theory, namely that the cost of public services is greater than the costs of identical services provided by the private sector. Additional research has hypothesized that a constraint on a monopoly government is competition from neighboring governments (Martin and Wagner, 1978). This research on the monopoly power of government has shown that restrictions on incorporation raise the costs of existing local governments.

Tests for leviathan government begin with the premise that such a system should be less likely to occur when government is relatively smaller and there exists strong intergovernmental competition. As with the studies of monopoly, much of the literature on leviathan has focused on local governments (Oates, 1972, Nelson, 1987, and Zax, 1989). The mixed results obtained in

${ }^{23}$ This is a result of the rational ignorance of voters (voters don't care about the political process because the costs of doing so outweigh any benefit from their single vote) and collusion by elected officials.

${ }^{24}$ A revenue-maximizing government will typically not maximize revenue at a 100 percent tax rate because a tax base shrinks as tax rates increase. Consider the following: $T=r \cdot B(r)$, where $T=\operatorname{tax}$ revenue, $r=$ tax rate, and $B=$ tax base. Differentiating tax revenue $(T)$ with respect to the tax rate $(r)$ and manipulating terms gives the expression

$$
\frac{\delta B}{\delta r} \cdot \frac{r}{B}=-1 .
$$

This expression shows that tax revenues will be maximized when the elasticity of the tax base is equal to -1 . If the elasticity is less than -1 , then an increase in the rate will decrease the base by a larger amount, thereby decreasing revenue. On the other hand, if the elasticity is greater than -1 , then an increase in the rate will decrease the base by a smaller amount, thereby increasing revenue. these studies are due, at least in part, to the variety of methods authors use to proxy for government size. On the national level, Oates (1985) finds that countries having a federalist constitution (many levels of government) had a negative, but insignificant, effect on government growth. Much more empirical testing must be done before the leviathan view of government is broadly accepted as one plausible explanation for government growth.

\section{A NOTE ON THE 16TH AMENDMENT TO THE U.S. CONSTITUTION}

Prior to the adoption of the 16th amendment to the U.S. Constitution in 1913, the federal government was constrained from directly taxing personal income by Article 1, Section 9 of the U.S. Constitution, which reads as follows: "No Capitation, or other direct, Tax shall be laid, unless in Proportion to the Census or Enumeration herein before directed to be taken." A careful reading of this clause reveals that the federal government actually could levy a personal income tax (which is a direct tax) prior to the 16th amendment, but income tax collection had to be in apportionment to population.

The 16th amendment negated the apportionment clause written in Article 1, Section 9. The 16th amendment reads as follows: "The Congress shall have the power to lay and collect taxes on incomes, from whatever sources derived, without apportionment among the several States, and without regard to any census or enumeration." The 16th amendment was passed by Congress on July 2, 1909, and ratified on February 3, 1913. ${ }^{25}$ What makes this amendment interesting with regard to government growth is that the dramatic rise in the size of the federal government (see Figure 1) began immediately following the ratification of the 16th amendment.

The option to levy a federal income tax that is made available to Congress does not itself imply

\footnotetext{
${ }^{25}$ For an interesting history of the 16th amendment, see National Archives and Records Administration (1995) and www.ourdocuments.gov (keyword search "16th amendment").
} 
that government will grow. The option to tax personal income means only that government has another source of revenue with on which to finance its growth. Explaining government growth must be done using the theories presented earlierincome taxes are simply a fuel that enables the engine of government growth to start.

However, the government has increased its reliance on federal income taxes over the past 90 years, the same time period in which government expenditures have increased dramatically. Personal income tax revenue as a percentage of all federal tax revenue increased from about 2 percent in 1913 to over 43 percent in 2004. Also, because of large exemptions, few people paid personal income taxes in 1913; if they did pay taxes, the rates were much lower than today. For example, in 1913 the lowest tax bracket was $\$ 0$ to $\$ 20,000$, with a 1 percent marginal tax rate; the highest bracket was on taxable income over $\$ 500,000$, taxed at a 7 percent rate; and the personal married exemption was $\$ 4,000$. In 2004 dollars, the lowest 1913 bracket and married exemption would be equal to $\$ 381,616$ and $\$ 76,323$, respectively, and the top 1913 bracket would be equal to a 2004 income of $\$ 10,495,000 .{ }^{26}$ Compare this with actual 2004 tax statistics: The married exemption (no children) was $\$ 6,200$, the lowest tax bracket was 10 percent on taxable income up to $\$ 7,150$, and the top marginal tax rate was 35 percent on taxable income over $\$ 319,100 .{ }^{27}$ Although the strength of any causality between the 16th amendment and later expansions of the income tax must be determined empirically, the strong correlation between these two events is compelling. ${ }^{28}$

\section{SUMMARY AND CONCLUSIONS}

The past 90 years has seen a dramatic rise in the size and growth of the government in the United States. This article presented various data illustrating this increase in government growth

\footnotetext{
${ }^{26}$ Calculations were made using the consumer price index (CPI).

${ }^{27}$ Internal Revenue Service: www.irs.gov/pub/irs-soi/02inpetr.pdf and 2004 Form 1040.

${ }^{28}$ Holcombe and LaCombe (1998) discuss the ratification of the 16th amendment and government growth.
}

and then focused on several economic theories that attempt to explain this growth. The theories fit into one of two philosophies of government growth: either (i) the growth of government is driven by citizen demand or (ii) the growth in government is a result of government itself, brought on by inherent inefficiencies in the public sector, the personal incentives of public officials, and representative democracy.

The theories discussed in this article are not the only theories on government growth that have been raised. Researchers have suggested that electoral cycles, in conjunction with citizen demand, may play a role in the size and growth of government (Downs, 1957, and Coughlin, 1992). The expansion of the voting franchise, an arguably more controversial explanation for government growth, was suggested by Meltzer and Richard (1981); their idea is that groups of individuals that were given the right to vote were typically from the lower end of the income distribution and demanded greater government services.

Although each theory was presented here as a stand-alone explanation for government size and growth, the complexity of the public sector and the political process as well as the limits of empirical economic analysis suggest that government growth is likely to be a function of some or all of the above theories. In addition, many of the theories do a better job at either explaining size or growth, but do not adequately explain the current size of government or its growth over time. Some of the theories have not withstood empirical tests, and debate continues as to whether this is a result of incorrect theory or incorrect empirical modeling. The challenge for economists and political scientists is to formulate a single cohesive theory that accounts for all aspects of the citizen-over-state and state-over-citizen theories presented here.

\section{REFERENCES}

Ahlbrandt, Roger S. Jr. "Efficiency in the Provision of Fire Services.” Public Choice, Fall 1973, 16, pp. 1-15.

Baumol, William J. “The Macroeconomics of Unbalanced Growth: The Anatomy of Urban Crisis.” 


\section{Garrett and Rhine}

American Economic Review, June 1967, 57(3), pp. 415-26.

Becker, Gary S. "A Theory of Competition among Pressure Groups for Political Influence.” Quarterly Journal of Economics, August 1983, 98(3), pp. 371400.

Bendor, Jonathan; Taylor, Serge and Van Gaalen, Roland. "Bureaucratic Expertise versus Legislative Authority: A Model of Deception and Monitoring in Budgeting." American Political Science Review, December 1985, 79(4), pp. 1041-60.

Bennett, James T. and Johnson, Manuel H. "Public versus Private Provision of Collective Goods and Services: Garbage Collection Revisited." Public Choice, 1979, 34(1), pp. 55-63.

Brennan, Geoffrey and Buchanan, James M. "Towards a Tax Constitution for Leviathan." Journal of Public Economics, December 1977, 8(3), pp. 255-73.

Brennan, Geoffrey and Buchanan, James M. The Power to Tax: Analytical Foundations of a Fiscal Constitution. Cambridge: Cambridge University Press, 1980.

Breton, Albert. The Economic Theory of Representative Government. Chicago: Aldine, 1974.

Buchanan, James. Public Finance in Democratic Processes. Chapel Hill, NC: University of North Carolina Press, 1967.

Chernick, Howard. "An Econometric Model of the Distribution of Project Grants," in P. Mieszkowski and W. Oakland, eds., Fiscal Federalism and Grantsin-Aid. Washington, DC: The Urban Institute, 1979.

Clarkson, Kenneth W. "Some Implications of Property Rights in Hospital Management." Journal of Law and Economics, October 1972, 15(2), pp. 363-84.

Coughlin, Peter. Probabilistic Voting Theory. Cambridge: Cambridge University Press, 1992.

Downs, Anthony. An Economic Theory of Democracy. New York: Harper and Row, 1957.
Downs, Anthony. "Problems of Majority Voting: In Defense of Majority Voting," Journal of Political Economy, April 1961, 69(2), pp. 192-99.

Ekelund, Robert and Tollison, Robert. "The Interest Group Theory of Government," in William Shughart and Laura Razzolini, eds., The Elgar Companion To Public Choice. Northhampton: Edward Elgar, 2001, pp. 357-78.

Ferris, J. Stephen and West, Edwin G. "Cost Disease verses Leviathan Explanations of Rising Government Costs: An Empirical Investigation." Public Choice, March 1999, 98(3-4), pp. 307-16.

Fisher, Ronald. State and Local Public Finance. Chicago: Irwin, 1996.

Friedman, Milton and Schwartz, Anna J. A Monetary History of the United States, 1867-1960. Princeton: Princeton University Press, 1963.

Garrett, Thomas A. and Rhine, Russell M. "Social Security verses Private Retirement Accounts: A Historical Analysis.” Federal Reserve Bank of St. Louis Review, March/April 2005, 87(2), Part 1, pp. 103-21.

Gwartney, James and Stroup, Richard L. Microeconomics: Private and Public Choice. 8th Edition. Chicago: Dryden Press, 1997.

Hamilton, Bruce W. "The Fly Paper Effect and Other Anomalies." Journal of Public Economics, December 1983, 22(3), pp. 347-61.

Hayek, Frederick A. von. The Road to Serfdom. London: George Routledge and Sons, 1944.

Hines, James R. Jr. and Thaler, Richard H. "The Fly Paper Effect.” The Journal of Economic Perspectives, Fall 1995, 9(4), pp. 217-26.

Holcombe, Randall G. and Lacombe, Donald J. "Interests versus Ideology in the Ratification of the 16th and 17th Amendments." Economics and Politics, July 1998, 10(2), pp. 143-59.

Hotelling, Harold. "Stability in Competition." Economic Journal, March 1929, 39(153), pp. 41-57. 
Kemper, Peter and Quigley, John M. The Economics of Refuse Collection. Cambridge, MA: Balinger, 1976.

Keynes, John Maynard. The General Theory of Employment, Interest, and Money. New York: Harcourt Brace, 1936.

Kliesen, Kevin. "Big Government. The Comeback Kid?” Federal Reserve Bank of St. Louis Regional Economist, January 2003.

Kristov, Lorenzo; Lindert, Peter and McClelland, Robert. "Pressure Groups and Redistribution." Journal of Public Economics, July 1992, 48(2), pp. 135-63.

Martin, Dolores T. and Wagner, Richard E. "The Institutional Framework for Municipal Incorporations: An Economic Analysis of Local Agency Formation Commissions in California." Journal of Law and Economics, October 1978, 21(2), pp. 409-25.

McCormick, Robert and Tollison, Robert. Politicians, Legislation, and the Economy: An Inquiry into the Interest Group Theory of Government. Boston: Martinus Nijhoff, 1981.

Meltzer, Allan H. and Richard, Scott F. "Why Government Grows (and Grows) in a Democracy." Public Interest, Summer 1978, 52, pp. 111-18.

Meltzer, Allan H. and Richard, Scott F. "A Rational Theory of the Size of Government." Journal of Political Economy, October 1981, 89(5), pp. 914-27.

Meltzer, Allan H. and Richard, Scott F. "Tests of a Rational Theory of the Size of Government.” Public Choice, 1983, 41(3), pp. 403-18.

Moe, Terry M. The Organization of Interests: Incentives and the Internal Dynamics of Political Interest Groups. Chicago: University of Chicago Press, 1980.

Morgan, W. "Investor Owned vs. Publicly Owned Water Agencies: An Evaluation of the Property Rights Theory of the Firm." Water Resources Bulletin, 1977, 13(4), pp. 775-81.

Mueller, Dennis C. Public Choice III. Cambridge: Cambridge University Press, 2003.
Mueller, Dennis and Murrell, Peter. "Interest Groups and the Political Economy of Government Size," in Francesco Forte and Alan Peacock, eds., Public Expenditures and Government Growth. Oxford: Basil Blackwell, 1985.

Mueller, Dennis C. and Murrell, Peter. "Interest Groups and the Size of Government." Public Choice, 1986, 48(2), pp. 125-45.

National Archives and Records Administration. Milestone Documents in the National Archives. Washington, DC: 1995, pp. 69-73.

Nelson, Michael A. "Searching for Leviathan: Comment and Extension." American Economic Review, March 1987, 77(1), pp. 198-204.

Niskanen, William. Bureaucracy and Representative Government. Chicago: Aldine-Atherton, 1971.

Niskanen, William. "Bureaucracy," in William Shughart and Laura Razzolini, eds., The Elgar Companion To Public Choice. Northhampton: Edward Elgar, 2001.

Oates, Wallace E. Fiscal Federalism. New York: Harcourt Brace Jovanovich, 1972.

Oates, Wallace E. "Searching for Leviathan: An Empirical Study.” American Economic Review, September 1985, 75(4), pp. 748-57.

Oates, Wallace E. "On the Nature and Measurement of Fiscal Illusion: A Survey,” in G. Brennan et al., eds., Taxation and Fiscal Federalism: Essays in Honour of Russell Mathews. Sydney: Australian National University Press, 1988.

Olson, Mancur. The Logic of Collective Action: Public Goods and the Theory of Groups. Cambridge: Harvard University Press, 1965.

Peltzman, Sam. "The Growth of Government." Journal of Law and Economics, October 1980, 23(2), pp. 209-87.

Rodrik, Dani. "Why Do More Open Economies Have Bigger Governments," Journal of Political Economy, October 1998, 106(5), pp. 997-1032. 


\section{Garrett and Rhine}

Sobel, Russell S. "The Budget Surplus: A Public Choice Explanation.” Working Paper 2001-05, West Virginia University, 2001.

Tullock, Gordon. "Problems of Majority Voting." Journal of Political Economy, December 1959, 67(6), pp. 571-79.

Weingast, Barry R.; Shepsle, Kenneth A. and Johnsen, Christopher. "The Political Economy of Benefits and Costs: A Neoclassical Approach to Distributive Politics." Journal of Political Economy, August 1981, 89(4), pp. 642-64.

Yergin, Daniel and Stanislaw, Joseph. The Commanding Heights: The Battle for the World Economy. New York: Simon and Schuster, 2002.

Zax, Jeffrey S. "Is There a Leviathan in Your Neighborhood?" American Economic Review, June 1989, 79(3), pp. 560-67. 